\title{
Pasting Properties of White Corn Flours of Anoman 1 and Pulut Harapan Varieties as Affected by Fementation Process
}

\author{
Rahmawati Farasara1,2, Purwiyatno Hariyadi1,3, Dedi Fardiaz ${ }^{1,3}$, Ratih Dewanti-Hariyadi 1,3 \\ ${ }^{1}$ Department of Food Science and Technology, Bogor Agricultural University, \\ Bogor, Indonesia \\ ${ }^{2}$ Department of Food Technology, Sahid University, Jakarta, Indonesia \\ ${ }^{3}$ Southeast Asia Food Agricultural Science and Technology (SEAFAST) Center, Bogor Agricultural University, \\ Bogor, Indonesia \\ Email: hariyadi@seafast.org
}

Received 3 September 2014; revised 26 September 2014; accepted 13 October 2014

Copyright (C) 2014 by authors and Scientific Research Publishing Inc.

This work is licensed under the Creative Commons Attribution International License (CC BY).

http://creativecommons.org/licenses/by/4.0/

(c) (†) Open Access

\begin{abstract}
This research was aimed to evaluate the pasting properties of white corn flour made from Anoman 1 and Pulut Harapan varieties as affected by the fermentation process of the corn grits. The fermentation process studied were 1) spontaneous fermentation (SF); 2) fermentation with the addition of a complete starter culture at 0 hour (CC fermentation) and 3) fermentation of (CC) with additional inoculation of starter culture containing amylolytic microorganisms at 16 hours (AC fermentation). The evaluation of pasting properties was done on the flour made from corn grits fermented for $0,36,48$, and 72 hours. Our results showed that pasting properties of corn flour of Anoman 1 and Pulut Harapan varieties were affected by fermentation process. Addition of starter culture in the fermentation showed more complex effect on the pasting properties and was a function of the fermentation time. Fermentation process of corn grits affected the pasting properties of the resulted flour, both for Anoman I and Pulut Harapan corn varieties. The differences in the effect of fermentation process on the pasting properties were due to the different amylose/amylopectin content. AC fermentation of corn grits could increase the stability of paste for flour containing higher amylose content but decrease the stability of paste for flour containing high amylopectin. Specifically, CC fermentation caused significant increase in the peak viscosity value especially for corn flour of Pulut Harapan. Fermentation for up to $48 \mathrm{~h}$ had resulted in corn flour of Pulut Harapan variety having a higher PV value, but it did not affect the tendency to retrograde.
\end{abstract}

\section{Keywords}

Pasting, Corn Flour, White Corn, Fermentation 


\section{Introduction}

Corn is an important carbohydrate source after rice in Indonesia. However, the utilization of corn flours and/or starches in native form is limited due to its physical properties, especially with regard to the retrogradation properties, syneresis of pasta, and low stability of pasta at high temperature and at low pH [1]. Consequently, there is a need to modify flour properties to improve its pasting properties.

Traditionally, corn flour is made by soaking corn kernels in water followed by the process of draining, drying and milling. Aini et al. (2010) [2] showed that changes in the physicochemical properties of white corn flour produced was attributable to the spontaneous fermentation occurring during soaking. Several other studies of spontaneous fermentation of corn have been published, such as in the production of ogi [3] and pozol [4] which are African traditional foods.

Previously, we have identified that microorganisms responsible for the spontaneous fermentation of corn were Penicillium chrysogenum, Penicillium citrinum, Aspergillus flavus, A. niger, Rhizopus stolonifer, R.oryzae, Fusarium oxysporum, Acremonium strictum, Candida famata, Kodamaea ohmeri, Candida krusei/incospicua, Lactobacillus plantarum1a, Pediococcus pentosaceus, Lactobacillus brevis1, Lactobacillus plantarum1b, and Lactobacillus paracasei ssp. paracasei3 [5]. Of all microorganisms identified; four molds (Penicillium citrinum, Aspergillus flavus, Aspergillus niger, Acremonium strictum) and one yeast (Candida famata) were found to be amylolytic, while none of the LAB was capable of starch hydrolysis. The amylolytic activity is thought to be important for physicochemical changes of flour due to its high carbohydrate content.

Since microorganisms were involved in the spontaneous fermentation (SF) of corn, the influence of addition of starter culture to the fermentation process on the pasting property of the resulted corn flour was evaluated. A complete starter culture (CC) was made using all microorganisms indentified responsible for the spontaneous fermentation of corn [5], except for Aspergillus flavus, due to its ability to produce aflatoxin in corn. Microorganisme used for preparation of complete culture were Penicillium chrysogenum, Penicillium citrinum, Aspergillus niger, Rhizopus stolonifer, Rhizopus oryzae, Fusarium oxysporum, Acremonium strictum, Candida famata, Kodamaea ohmeri, Candida krusei/incospicua, Lactobacillus plantarum1a, Pediococcus pentosaceus, L. brevis1, L. plantarum 1 b, and L. paracasei ssp. paracasei3. In addition, an amylolytic starter culture (AC) was made using the three amylolytic molds (without Aspergillus flavus) and one amylolytic yeast.

Three experiments of fermentations process of corn grits were conducted, i.e. spontaneous fermentation (SF) by water soaking of corn grits as a control, fermentation with addition of complete starter culture (CC) from the start of fermentation, and treatment of (CC) with additional amylolytic starter culture (AC) after 16 hours of fermentation. Observations were done on the flour made from corn grits after 0 (unfermented flour, U), 36, 48, and 72 hours of fermentation.

\section{Materials and Methods}

\subsection{Corn}

Corn types used in this research were local white maize Anoman 1 and waxy maize Pulut Harapan varieties obtained from the Cereal Crops Research Institute, Maros, Sulawesi, Indonesia. Anoman 1 maize kernel contains high amylose (29.92\%), while the waxy maize kernel local Pulut has low amylose content (4.25\%) [6].

Corn was made into grits for a more standardized fermentation process. Kernels of corn were washed with drinking water (corn: water $=1: 4 \mathrm{w} / \mathrm{v}$ ) and drained on a siever. Drained and clean corn kernels were then ground using pin disc mill and sieved to produce grits with diameter of $\geq 4 \mathrm{~mm}$. The grits were washed with drinking water (corn grits: water $=1: 4 \mathrm{w} / \mathrm{v}$ ) for 30 minutes and then drained and ready for fermentation.

\subsection{Microorganisms}

Microorganisms used for starter culture preparation were amylolytic Penicillium citrinum, Aspergillus niger, Acremonium strictum, and Candida famata, as well as non amylolytic Penicillium chrysogenum, Rhizopus stolonifer, Rhizopus oryzae, Fusarium oxysporum, Kodamaea ohmeri and Candida krusei/incospicua, Lactobacillus plantarum1a, Pediococcus pentosaceus, Lactobacillus brevis1, and Lactobacillus paracasei ssp. paracasei3. The microorganisms used were previously isolated and identified from a spontaneous fermentation of corn grits [5], at which for lactic acid bacteria were identified using API kits program API CH50 (biochemical rapid kits, bioMérieux). 


\subsection{Culture Preparation and Enumeration}

One loop of each mold was streaked onto fresh Potato Dextrose Agar (PDA) slant and then incubated at $30^{\circ} \mathrm{C}$ for 5 days. After 5 days molds were harvested by scrapping, suspended in $10 \mathrm{~mL}$ sterile water and appropriately diluted for enumeration using hemacytometer. Yeast culture was prepared as above but incubation was carried out at $30^{\circ} \mathrm{C}$ for 2 days. Yeast enumeration was also carried out using hemacytometer. Meanwhile Lactic Acid Bacteria (LAB) cultures were prepared by transferring one loop of each LAB growth into de Man Rogosa Sharpe (MRS) Broth for 24 hours at $30^{\circ} \mathrm{C}$ using shaking incubator. After 24 hours, the culture was centrifuged aseptically for 15 mins, $3500 \mathrm{rpm}$ at $4^{\circ} \mathrm{C}$ and the cell pellets were resuspended in phosphate buffer. The $24 \mathrm{~h}$ culture was also enumerated by plating on MRS agar.

\subsection{Fermentation with Added Starter Culture}

Five days old molds and two days old yeast in sterile water as well as 24 hours LAB in phosphate buffer made up the complete starter culture. For amylolytic starter culture, only Penicillium citrinum, Aspergillus niger, Acremonium strictum, and Candida famata were used. Each microorganism was inoculated aseptically into container $(15 \mathrm{~L})$ containing of maize grits and drinking water $(1: 2 \mathrm{w} / \mathrm{v})$ such that each microorganism has an initial load of ca. $10^{6} \mathrm{CFU} / \mathrm{mL}$.

The fermentation studied included spontaneous fermentation, i.e. water soaking of corn grits as a control (SF) and fermentation with added starter cultures. Two treatments of fermentation with added starter were (CC) a complete starter culture containing 15 microbes previously isolated from the spontaneous fermentation added at the beginning of fermentation (0 hours), and (AC) fermentation of (CC) with additional inoculation of amylolytic starter culture at 16 hours of fermentation. Observations were done on flour made from corn grits after 0 , 36, 48, and 72 hours fermentation.

\subsection{Pasting Properties of Corn Flours Measured Using Rapid Visco Analyzer TecMaster Newport Scientific Pty Limited Australia (RVA Standard 2)}

Corn flour samples of $3.5 \mathrm{~g}$ (14\% moisture content) were added to $25 \mathrm{~mL}$ of distilled water in an aluminum can. Sample was spinned $(160 \mathrm{rpm})$ at $50^{\circ} \mathrm{C}$ for $1 \mathrm{~min}$, and heated to reach $95^{\circ} \mathrm{C}$ within $7.5 \mathrm{~min}$, and held at $95^{\circ} \mathrm{C}$ for $5 \mathrm{~min}$, and then cooled back to $50^{\circ} \mathrm{C}$ within $7.5 \mathrm{~min}$ and held at $50^{\circ} \mathrm{C}$ for additional $2 \mathrm{~min}$. A typical complete RVA curve obtained is presented in Figure 1.

Parameters derived from the RVA curve were peak viscosity (PV); trough viscosity (TV; also called as hot

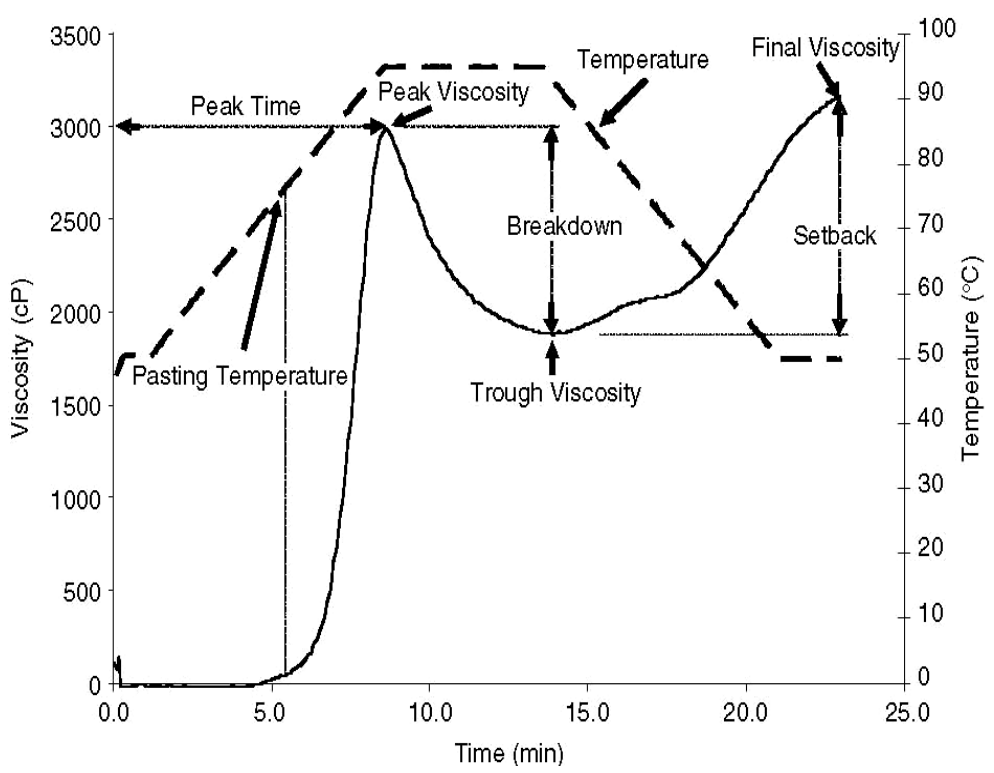

Figure 1. Typical pasting profile obtained by RVA, showing the main parameters used to described pasting properties. 
viscosity), and final viscosity (FV). The breakdown (BV) and setback (SV) viscosities were calculated from the differences between (PV and TV) and (FV and TV), respectively.

\subsection{Statistical Analysis}

Statistical signifcance of differences between sample means was determined using analysis of variance (ANOVA) followed by Duncan’s Multiple Range Test at 95\% confidence level.

\section{Results and Discussion}

Our results showed that pasting properties of corn flour of Anoman 1 and Pulut Harapan varieties were affected by fermentation process. Addition of starter culture for the fermentation showed more complex effect on the pasting properties and was a function of the progress of fermentation reaction.

\subsection{Pasting Properties of Corn Flours after 36 Hours of Fermentation}

The pasting profiles (Figure 2) and parameters (Table 1) of corn flours made from corn grits after 36 hours of

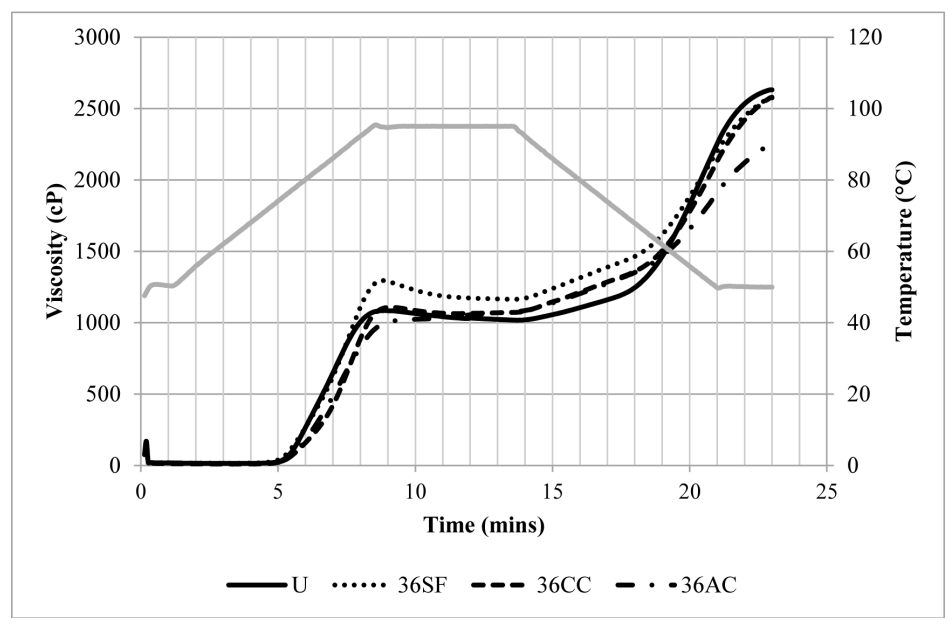

(a)

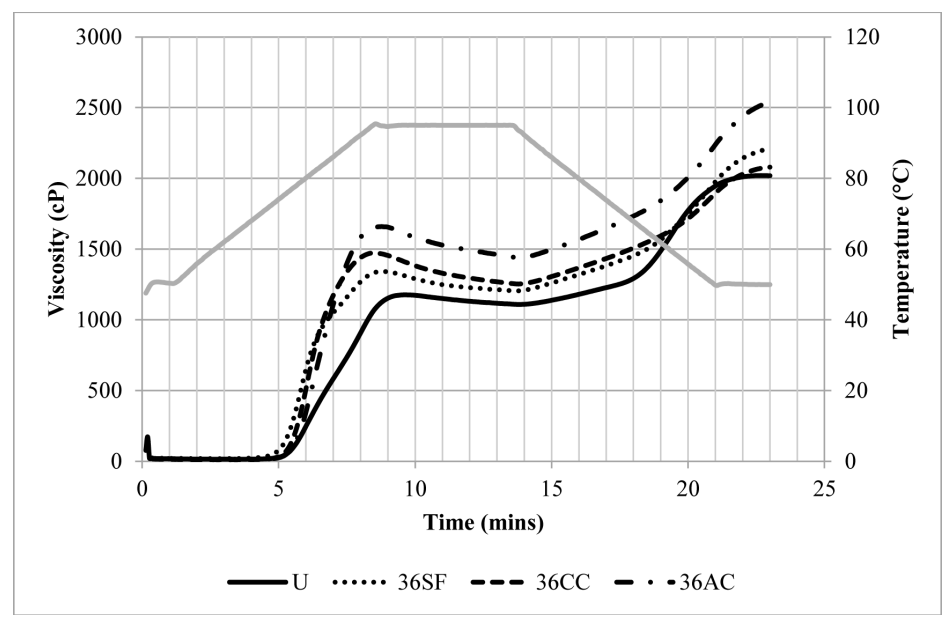

(b)

Figure 2. Pasting profile of corn flour of Anoman 1 (a) and Pulut Harapan (b) varieties made from corn grits after 36 hours of fermentation. U: Unfermented flours; 36SF: flour made from corn grits after 36 hours of spontaneous fermentation, 36CC: flour made from corn grits after 36 hours of fermentation with addition of a complete starter culture; 36AC: flour made from corn grits after 36 hours of fermentation with complete culture and additional amylolytic starter (AC) culture at 16 hours of fermentation. 
Table 1. Pasting properties profile of maize flour Anoman 1and Pulut Harapan varieties during 36 hours fermentation.

\begin{tabular}{|c|c|c|c|c|c|c|}
\hline Treatments & $\begin{array}{l}\text { Pasting temperature } \\
\left({ }^{\circ} \mathrm{C}\right)\end{array}$ & Peak viscosity (cP) & $\begin{array}{l}\text { Trough viscosity } \\
\text { (cP) }\end{array}$ & $\begin{array}{l}\text { Breakdown } \\
\text { viscosity (cP) }\end{array}$ & Final viscosity (cP) & $\begin{array}{l}\text { Setback viscosity } \\
\text { (cP) }\end{array}$ \\
\hline \multicolumn{7}{|c|}{ Anoman 1 flour } \\
\hline $\mathrm{U}$ & $81.5 \pm 30.9^{\mathrm{a}}$ & $1276.9 \pm 24.4^{\mathrm{a}}$ & $1012.6 \pm 27.6^{\mathrm{a}}$ & $264.4 \pm 36.4^{\mathrm{b}}$ & $2630.8 \pm 0.1^{\mathrm{c}}$ & $1618.3 \pm 0.4^{\mathrm{c}}$ \\
\hline $36 \mathrm{SF}$ & $83.4 \pm 28.7^{\mathrm{a}}$ & $1451.9 \pm 14.8^{\mathrm{b}}$ & $1156.3 \pm 29.7^{\mathrm{b}}$ & $295.6 \pm 35.7^{c}$ & $2579.4 \pm 0.0^{\mathrm{b}}$ & $1423.1 \pm 0.3^{\mathrm{b}}$ \\
\hline $36 C C$ & $85.0 \pm 24.5^{\mathrm{a}}$ & $1290.4 \pm 8.8^{\mathrm{b}}$ & $1062.6 \pm 23.3^{\mathrm{b}}$ & $227.8 \pm 21.7^{\mathrm{bc}}$ & $2575.1 \pm 0.0^{\mathrm{bc}}$ & $1512.5 \pm 0.3^{b}$ \\
\hline $36 \mathrm{AC}$ & $82.2 \pm 48.8^{\mathrm{a}}$ & $1193.8 \pm 22.6^{a}$ & $1065.8 \pm 64.3^{\mathrm{b}}$ & $128.0 \pm 62.6^{\mathrm{a}}$ & $2249.0 \pm 0.1^{\mathrm{a}}$ & $1183.3 \pm 0.5^{\mathrm{a}}$ \\
\hline \multicolumn{7}{|c|}{ Pulut Harapan flour } \\
\hline $\mathrm{U}$ & $82.1 \pm 25.9^{\mathrm{a}}$ & $1237.7 \pm 20.7^{\mathrm{a}}$ & $1090.3 \pm 29.5^{\mathrm{a}}$ & $147.4 \pm 15.8^{\mathrm{a}}$ & $2017.4 \pm 0.7^{\mathrm{a}}$ & $927.1 \pm 0.8^{\mathrm{a}}$ \\
\hline $36 \mathrm{SF}$ & $75.6 \pm 37.2^{\mathrm{a}}$ & $1680.2 \pm 33.3^{\mathrm{b}}$ & $1248.6 \pm 24.0^{\mathrm{b}}$ & $431.6 \pm 22.3^{b}$ & $2443.4 \pm 0.0^{\mathrm{bc}}$ & $1194.8 \pm 0.8^{\mathrm{a}}$ \\
\hline $36 \mathrm{CC}$ & $78.4 \pm 23.1^{\mathrm{a}}$ & $1638.4 \pm 15.4^{\mathrm{b}}$ & $1251.9 \pm 21.1^{\mathrm{bc}}$ & $386.6 \pm 18.2^{\mathrm{b}}$ & $2079.4 \pm 0.1^{\mathrm{b}}$ & $827.6 \pm 0.2^{\mathrm{a}}$ \\
\hline $36 \mathrm{AC}$ & $78.5 \pm 9.9^{\mathrm{a}}$ & $1790.0 \pm 48.1^{\mathrm{c}}$ & $1439.3 \pm 52.7^{c}$ & $350.8 \pm 32.5^{\mathrm{b}}$ & $2537.1 \pm 1.0^{c}$ & $1097.9 \pm 2.4^{\mathrm{a}}$ \\
\hline
\end{tabular}

Samples means with different superscripts in the same column are significantly different $(\mathrm{p}<0.05)$ by Duncan's multiple range test.

fermentation both for Anoman I and Pulut Harapan varieties obtained from the RVA curve were evaluated. Unfermented corn flour of Anoman I and Pulut Harapan varieties has peak viscosities (PV) of $1276.9 \pm 24.4 \mathrm{cP}$ and $1237.7 \pm 20.7 \mathrm{cP}$, respectively (Table 1). Spontaneous fermentation for 36 hours (36SF) increased PV of flours from both corn varieties to1451.9 $\pm 14.8 \mathrm{cP}$ and $1680.2 \pm 33.3 \mathrm{cP}$, respectively for Anoman 1 and Pulut Harapan. Increase of PV is associated with enzymatic activity during fermentation process. Rhizopus oryzae has been shown to produce cellulase, hemicellulase, pectinase, tannase, phytase, lipase and protease [7], while Rhizopus stolonifer produces cellulase [8]. Beside its amylolytic activity, Aspergillus niger also has pectinolytic activity [5] [9]. Panagiotou et al. [10] reported that Fusarium oxysporum has cellulolytic and xylanolytic activity. Kodamae ohmeri produces phytase in cereals [11] and lipase [12]. Candida famata produced glucoamylase [13], as well as has lypolytic and proteolytic activity [14]. Candida krusei has lypolytic and esterase activity which contribute on the flavor of end product [15]. Amylase hydrolyzes $\alpha-1,4$-D-glycosidic bond of starch [16] thus the structure of starch granule becomes more porous facilitating water absorption to granules. This will increase the swelling of granules [17] and increase PV. PV illustrates the capacity of starch in absorbing water and swelling of granules when it is heated [18].

Inoculation of a complete starter culture (CC) however reduced the PV of the corn flour of Anoman I variety to $1290.4 \pm 8.8 \mathrm{cP}$. This is due to excessive amylolytic activity leading to more amylose breakdown. Different phenomenon was observed for corn flour of Pulut Harapan variety; which showed that its PV was as high as that of flour obtained from corn grits after 36 hours of spontaneous fermentation (36SF; $1680.2 \pm 33.3$ cP). Addition of amylolytic culture, however, caused further increase of PV for corn flour of Pulut Harapan variety. This is due to the lower content of amylose (higher content of amylopectin) of corn flour of Pulut Harapan variety. Structurally, the higher amylopectin content of Pulut Harapan corn support granule to be more resistant to amylolytic activity during fermentation. Since the flour has stronger granule integrity, it will swell bigger and has increased peak viscosity.

The viscosity of flour paste decreased after heating process for certain period due the granule breakdown followed by leaching of amylose into the solution [19]. The degree of viscosity reduction during heating process is termed as breakdown viscosity (BV); and can be used as an indicator for pasting stability during heating and stirring [20] [21].

As we can see from Table 1, the breakdown (BV), final (FV) and setback (SV) viscosities of Anoman 1 corn flour prepared from corn grits after 36 hours spontaneous fermentation were relatively lower than that of unfermented flour. This suggests that high amlyose content of corn of Anoman variety is more sensitive toward amylolytic activity during the 36 hours of fermentation. This also apparent with reduced final viscosity (FV) observed; especially those with amylolytic culture added (AC). FV is a viscosity at $50^{\circ} \mathrm{C}$ at the end of analysis. FV indicates the stability of paste during cooling process. At the end of cooling process of 95 to $50^{\circ} \mathrm{C}$, the viscosity increased. This is due to the alignment and rearrangement the amylose chain [18] [21]. During cooling process, 
amylose polymers start to aggregate through hydrogen bond forming a junction bond and generates a gel network, and is called retrogradation [22]. Reduction or breakdown of amylose at Anoman I corn is also indicated by the final viscosity drop from $2630.8 \pm 0.1 \mathrm{cP}$ for the unfermented flour to $2579.4 \pm 0.0 \mathrm{cP}$ due to spontaneous fermentation (36SF) and $2575.1 \pm 0.0 \mathrm{cP}$ due to fermentation with addition of complete culture (36CC). This may be associated with more amylolytic microbes causing more breakdown of amylose into simple sugar, thus reduced the final amylose level as indicated by the lower FV value. Further decrease in FV up to $2249.0 \pm 0.1$ cP observed due to additional amylolytic culture (36AC) also support this explanation, because further breakdown of amylose molecules occured (Table 1 ).

In general, the FV of unfermented flour of Pulut Harapan (2017.4 $\pm 0.7 \mathrm{cP}$ ) was lower than that of Anoman I (2630.8 $\pm 0.1 \mathrm{cP})$. This is associated with its higher amylopectin content of corn of Pulut Harapan. Flour containing higher amylopectin has shown to produce highly gelatinous dispersions when cooked and form soft and runny gels [22]. This is because amylopectin has more ability to absorb water than that of amylose [23]. Furthermore; for flour with low to medium amylose content, the present of higher percentage of amylopectin molecules may hamper aggregation of free amylose chains during aggregation [22]; as indicated by lower value of FV. After 36 hours of fermentation, however, flour of Pulut Harapan showed increased FV value (Figure 2(b); Table 1), suggesting more free amylose was produced to allow the formation of more viscous network. The least increase of FV (of $2079.4 \pm 0.1 \mathrm{cP}$ ) was observed for corn flour of Pulut Harapan obtained from 36 hour of fermentation with addition of complete culture starter (36CC). This suggests that addition of CC starter would hydrolyze amylose molecule to form shorter chain; reducing FV value. Further addition of amylolytic culture (36AC) however, will increase the FV value $(2537.1 \pm 1.0 \mathrm{cP})$. This might be associated with more amylose molecules produced by hydrolysis reaction of amylopectin molecules.

The stability of paste during cooling and storage is indicated by SV value; i.e. the differences between FV and TV values. The higher SV value indicates the higher tendency of amylose to retrograde [21] forming a gel structure when the polymer molecules, especially amylose chains, realign themselves. Our results shows that in general, fermentation has caused corn flour of Anoman I variety to have less tendency to retrograde (SV value of 1183.3 to $1512.5 \mathrm{cP}$ ) as compared to that of the unfermented one (SV value of $1618.3 \pm 0.4 \mathrm{cP}$ ). Corn flour of Anoman I with the lowest tendency to retrograde was the one produced from AC fermentation (SV value of $1183.3 \pm 0.5 \mathrm{cP}$ ); indicating a more intensive hydrolysis of amylose molecule occurred during the fermentation.

For Pulut Harapan corn, unfermented flour has an SV value of $927.1 \pm 0.8 \mathrm{cP}$ (Table 1). Our results showed that fermentation treatments increased tendency to retrograde, except for fermentation with addition of complete culture starter (SV value of $827.6 \pm 0.2 \mathrm{cP}$ ). Corn flour obtained after 36 hour of spontaneous fermentation (36SF) has an SV value of $1194.8 \pm 0.8 \mathrm{cP}$, and flour of 36AC has an SV value of $1097.9 \pm 2.4 \mathrm{cP}$. This phenomenon is related with their respective $\mathrm{FV}$; as explained in the previous paragraph.

\subsection{Pasting Properties of Corn Flours after 48 Hours of Fermentation}

Continued fermentation process of corn grits up to 48 hours of fermentation, resulted in corn flour with pasting profile as presented in Figure 3(a) (for Anoman I ) and 3B (for Pulut Harapan), with their respective pasting parameter presented at Table 2. In general, the PV value of corn flour of both Anoman 1 obtained from fer mented corn grits for 48 hours (48SF, 48 CC and 48AC; Figure 3(a)) is very similar to that of flour obtained from fermented corn grits for 36 hours (36SF, 36 CC and 36AC; Figure 2(a)). For corn of Pulut Harapan, the peak viscosity continued to increase to $1825.4 \pm 26.4$ (for 48SF) and $2134.5 \pm 29.7$ (for $48 \mathrm{AC}$ ) cP. Again, this phenomenon is associated with higher amylopectin content of Pulut Harapan corn flour because the flour is more resistant to enzymes and acid thus it was able to swell bigger. Interesting results were observed that all fermentation treatments has increased PV values of corn flour of Pulut Harapan variety; but it did not affect the tendency to retrograde; as indicated by the relatively similar SV value $(927.1 \pm 0.8 \mathrm{cP}$ for unfermented flour, 989.1 $\pm 1.1 \mathrm{cP}$ for SF, $935.1 \pm 0.2 \mathrm{cP}$ for CC and 924.4 $\pm 0.2 \mathrm{cP}$ for AC flours, Table 2).

\subsection{Pasting Properties of Corn Flours after 72 Hours of Fermentation}

The pasting profile and properties of corn flour of both Anoman 1 and Pulut Harapan obtained after $72 \mathrm{~h}$ of fermentation of corn grits was presented at Figure 4 and Table 3. Longer fermentation time (72 hour), the corn flour of Anoman 1 from fermented corn grits had higher value of PV; with the highest value (1487.1 $\pm 12.6 \mathrm{cP})$ 


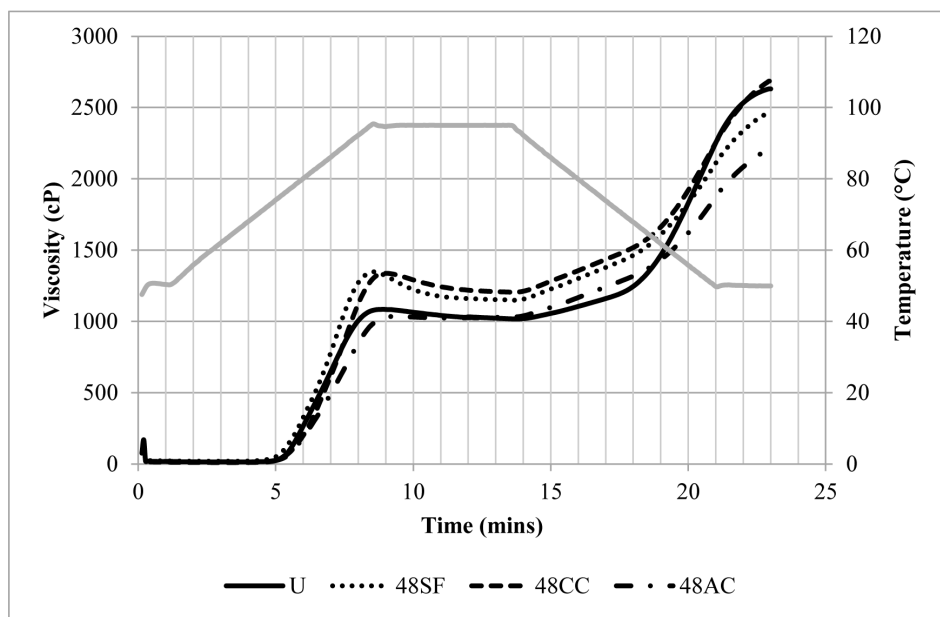

(a)

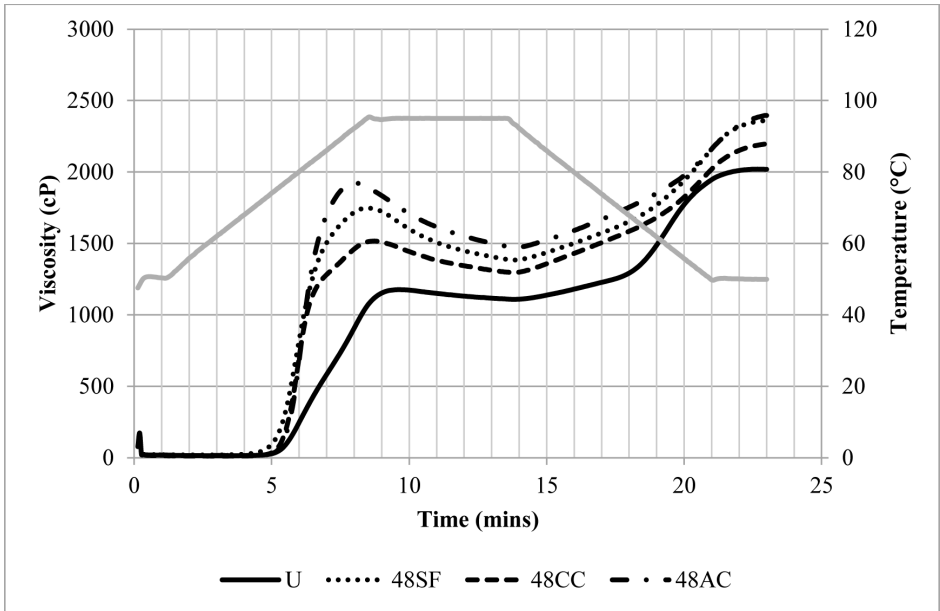

(b)

Figure 3. Pasting profile of corn flour of Anoman 1 (a) and Pulut Harapan (b) varieties made from corn grits after 48 hours of fermentation. U: Unfermented flours; 48SF: flour made from corn grits after 48 hours of spontaneous fermentation, 48CC: flour made from corn grits after 48 hours of fermentation with addition of a complete starter culture; 48AC: flour made from corn grits after 48 hours of fermentation with complete culture and additional amylolytic starter (AC) culture at 16 hours of fermentation.

Table 2. Pasting properties profile of maize flour Anoman 1and Pulut Harapan varieties during 48 hours fermentation.

\begin{tabular}{|c|c|c|c|c|c|c|}
\hline Treatments & $\begin{array}{c}\text { Pasting temperature } \\
\left({ }^{\circ} \mathrm{C}\right)\end{array}$ & Peak viscosity (cP) & $\begin{array}{l}\text { Trough viscosity } \\
\text { (cP) }\end{array}$ & $\begin{array}{c}\text { Breakdown } \\
\text { viscosity (cP) }\end{array}$ & Final viscosity (cP) & $\begin{array}{l}\text { Setback viscosity } \\
\text { (cP) }\end{array}$ \\
\hline \multicolumn{7}{|c|}{ Anoman 1 flour } \\
\hline $\mathrm{U}$ & $81.5 \pm 30.9^{\mathrm{a}}$ & $1276.9 \pm 24.4^{\mathrm{a}}$ & $1012.6 \pm 27.6^{\mathrm{a}}$ & $264.4 \pm 36.4^{\mathrm{b}}$ & $2630.8 \pm 0.1^{c}$ & $1618.3 \pm 0.4^{\mathrm{c}}$ \\
\hline $48 S F$ & $80.8 \pm 17.8^{\mathrm{a}}$ & $1432.6 \pm 4.9^{b}$ & $1121.7 \pm 23.4^{\mathrm{b}}$ & $310.9 \pm 17.1^{\mathrm{c}}$ & $2382.3 \pm 0.0^{\mathrm{b}}$ & $1260.6 \pm 1.3^{\mathrm{b}}$ \\
\hline 48CC & $83.8 \pm 11.7^{\mathrm{a}}$ & $1489.0 \pm 18.0^{\mathrm{b}}$ & $1175.2 \pm 29.8^{\mathrm{b}}$ & $313.8 \pm 30.9^{\mathrm{bc}}$ & $2645.9 \pm 0.0^{\mathrm{bc}}$ & $1470.8 \pm 0.3^{\mathrm{b}}$ \\
\hline $48 \mathrm{AC}$ & $81.8 \pm 32.5^{\mathrm{a}}$ & $1189.8 \pm 13.8^{\mathrm{a}}$ & $1021.3 \pm 47.1^{b}$ & $168.5 \pm 36.8^{\mathrm{a}}$ & $2213.0 \pm 0.0^{\mathrm{a}}$ & $1191.8 \pm 0.4^{\mathrm{a}}$ \\
\hline \multicolumn{7}{|c|}{ Pulut Harapan flour } \\
\hline $\mathrm{U}$ & $82.1 \pm 25.9^{\mathrm{a}}$ & $1237.7 \pm 20.7^{\mathrm{a}}$ & $1090.3 \pm 29.5^{\mathrm{a}}$ & $147.4 \pm 15.8^{\mathrm{a}}$ & $2017.4 \pm 0.7^{\mathrm{a}}$ & $927.1 \pm 0.8^{\mathrm{a}}$ \\
\hline $48 S F$ & $76.9 \pm 24.0^{\mathrm{a}}$ & $1901.8 \pm 29.6^{b}$ & $1326.6 \pm 48.3^{b}$ & $575.2 \pm 37.3^{\mathrm{b}}$ & $2315.7 \pm 0.0^{\mathrm{bc}}$ & $989.1 \pm 1.1^{\mathrm{a}}$ \\
\hline 48CC & $79.7 \pm 17.2^{\mathrm{a}}$ & $1825.4 \pm 26.4^{b}$ & $1298.9 \pm 38.4^{\mathrm{bc}}$ & $526.5 \pm 21.9^{b}$ & $2234.0 \pm 0.1^{b}$ & $935.1 \pm 0.2^{\mathrm{a}}$ \\
\hline $48 \mathrm{AC}$ & $78.1 \pm 49.7^{\mathrm{a}}$ & $2134.5 \pm 29.7^{c}$ & $1471.4 \pm 62.2^{\mathrm{b}}$ & $663.1 \pm 57.1^{\mathrm{b}}$ & $2395.8 \pm 0.4^{\mathrm{c}}$ & $924.4 \pm 0.2^{\mathrm{a}}$ \\
\hline
\end{tabular}

Samples means with different superscripts in the same column are significantly different $(\mathrm{p}<0.05)$ by Duncan's multiple range test. 


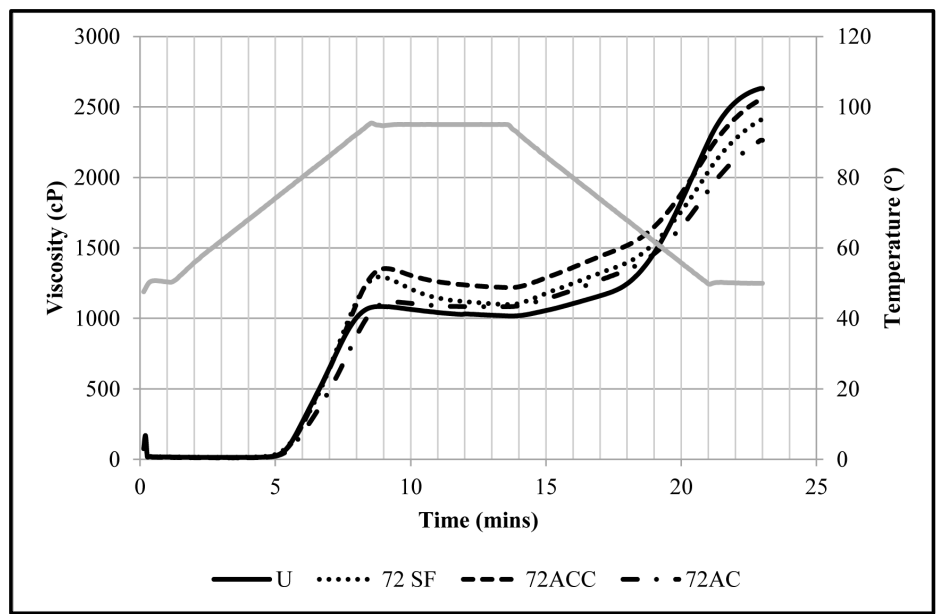

(a)

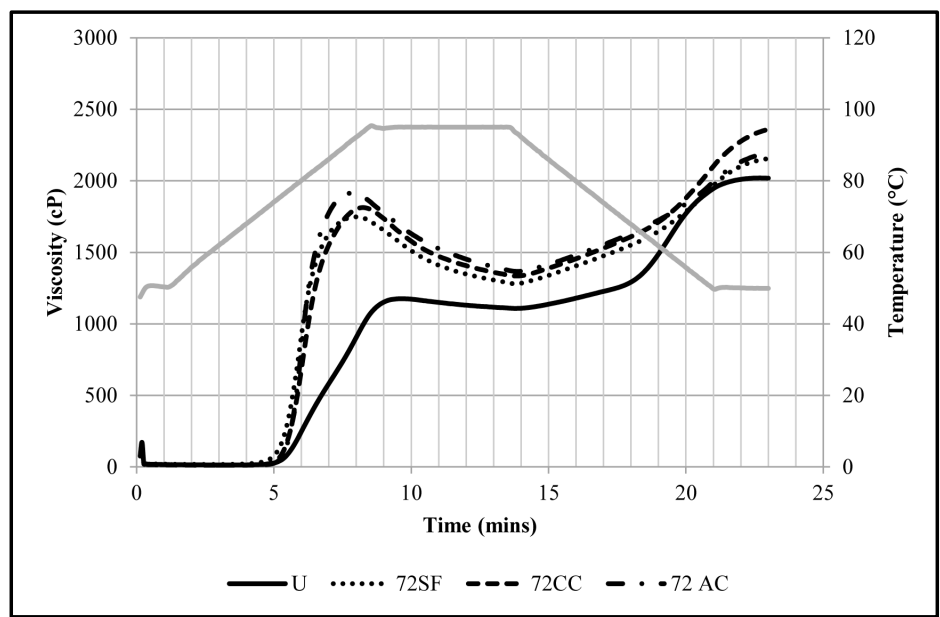

(b)

Figure 4. Pasting profile of corn flour of Anoman 1 (a) and Pulut Harapan (b) varieties made from corn grits after 72 hours of fermentation. U: Unfermented flours; 72SF: flour made from corn grits after 72 hours of spontaneous fermentation, 72CC: flour made from corn grits after 72 hours of fermentation with addition of a complete starter culture; 72AC: flour made from corn grits after 72 hours of fermentation with complete culture and additional amylolytic starter (AC) culture at 16 hours of fermentation.

Table 3. Pasting properties profile of maize flour Anoman 1 and Pulut Harapan varieties during 72 hours fermentation.

\begin{tabular}{|c|c|c|c|c|c|c|}
\hline Treatments & $\begin{array}{l}\text { Pasting temperature } \\
\left({ }^{\circ} \mathrm{C}\right)\end{array}$ & Peak viscosity (cP) & $\begin{array}{l}\text { Trough viscosity } \\
\text { (cP) }\end{array}$ & $\begin{array}{c}\text { Breakdown } \\
\text { viscosity (cP) }\end{array}$ & Final viscosity (cP) & $\begin{array}{l}\text { Setback viscosity } \\
\text { (cP) }\end{array}$ \\
\hline \multicolumn{7}{|c|}{ Anoman 1 flour } \\
\hline $\mathrm{U}$ & $81.5 \pm 30.9^{\mathrm{a}}$ & $1276.9 \pm 24.4^{\mathrm{a}}$ & $1012.6 \pm 27.6^{\mathrm{a}}$ & $264.4 \pm 36.4^{\mathrm{b}}$ & $2630.8 \pm 0.1^{\mathrm{c}}$ & $1618.3 \pm 0.4^{\mathrm{c}}$ \\
\hline 72SF & $83.3 \pm 14.0^{\mathrm{a}}$ & $1470.5 \pm 6.9^{\mathrm{b}}$ & $1113.6 \pm 26.9^{\mathrm{b}}$ & $356.9 \pm 26.6^{\mathrm{c}}$ & $2459.5 \pm 0.0^{\mathrm{b}}$ & $1345.9 \pm 0.2^{\mathrm{b}}$ \\
\hline 72CC & $82.7 \pm 10.3^{\mathrm{a}}$ & $1487.1 \pm 12.6^{\mathrm{b}}$ & $1179.6 \pm 12.5^{\mathrm{b}}$ & $307.4 \pm 13.9^{\mathrm{bc}}$ & $2427.9 \pm 0.1^{\mathrm{bc}}$ & $1248.3 \pm 0.1^{\mathrm{b}}$ \\
\hline $72 \mathrm{AC}$ & $82.0 \pm 23.3^{\mathrm{a}}$ & $1251.8 \pm 44.0^{\mathrm{a}}$ & $1238.3 \pm 43.6^{\mathrm{b}}$ & $176.6 \pm 33.7^{\mathrm{a}}$ & $2263.3 \pm 2.3^{\mathrm{a}}$ & $1188.1 \pm 4.1^{\mathrm{a}}$ \\
\hline \multicolumn{7}{|c|}{ Pulut Harapan flour } \\
\hline $\mathrm{U}$ & $82.1 \pm 25.9^{\mathrm{a}}$ & $1237.7 \pm 20.7^{\mathrm{a}}$ & $1090.3 \pm 29.5^{\mathrm{a}}$ & $147.4 \pm 15.8^{\mathrm{a}}$ & $2017.4 \pm 0.7^{\mathrm{a}}$ & $927.1 \pm 0.8^{\mathrm{a}}$ \\
\hline $72 \mathrm{SF}$ & $77.4 \pm 23.0^{\mathrm{a}}$ & $1701.0 \pm 37.7^{\mathrm{b}}$ & $1214.9 \pm 11.2^{\mathrm{b}}$ & $486.1 \pm 26.6^{\mathrm{b}}$ & $2091.8 \pm 0.1^{\mathrm{bc}}$ & $876.9 \pm 0.5^{\mathrm{a}}$ \\
\hline 72CC & $78.7 \pm 19.2^{\mathrm{a}}$ & $2038.0 \pm 4.4^{\mathrm{b}}$ & $1333.2 \pm 16.3^{\mathrm{bc}}$ & $704.8 \pm 9.2^{\mathrm{b}}$ & $2357.3 \pm 0.1^{\mathrm{b}}$ & $1024.1 \pm 0.2^{\mathrm{a}}$ \\
\hline $72 \mathrm{AC}$ & $77.9 \pm 47.8^{\mathrm{a}}$ & $2148.3 \pm 40.3^{\mathrm{c}}$ & $1203.1 \pm 40.9^{c}$ & $782.0 \pm 21.9^{\mathrm{b}}$ & $2190.4 \pm 2.0^{c}$ & $824.1 \pm 4.7^{\mathrm{a}}$ \\
\hline
\end{tabular}

Samples means with different superscripts in the same column are significantly different $(\mathrm{p}<0.05)$ by Duncan's multiple range test. 
observed in flour obtained from fermentation process with additional complete culture (72CC). Corn flour of Pulut Harapan obtained from fermentations of corn grits with additional complete culture (72CC) showed further increase in in PV $(2038.0 \pm 4.4 \mathrm{cP})$ much higher that that of corn flour obtained from 36 hours of fermentation (36 CC, $1825.4 \pm 26.4 \mathrm{cP}$ ).

\section{Conclusion}

Fermentation process of corn grits affected the pasting properties of the resulting flour, both for Anoman I and Pulut Harapan corn varieties. The differences in the effect of fermentation process on pasting properties were due to the different amylose content of the corn varieties; as observed in Anoman I (high amylose content) and Pulut Harapan (low amlyose content) varieties. The addition of starter culture containing amylolytic microorganisms at $16 \mathrm{~h}$ of fermentation (AC) resulted in corn flour of Anoman I with lower values of PV, BV, FV, and SV. Meanwhile for corn flour of Pulut Harapan variety, CC fermentation resulted in flour with higher value of $\mathrm{PV}, \mathrm{BV}, \mathrm{FV}$, and SV. In general, AC fermentation of corn grits could increase the stability of paste for flour containing higher amylose content but decrease the stability of paste for flour containing high amylopectin. Specifically, fermentation with complete starter culture (CC) caused significant increase in the peak viscosity value especially for corn flour of Pulut Harapan. Fermentation for up to $48 \mathrm{~h}$ had resulted in corn flour of Pulut Harapan variety having higher value of PV; but it did not affect the tendency to retrograde.

\section{References}

[1] Aini, N. and Hariyadi, P. (2010) Gelatinization Properties of White Maize Starch from Three Varieties of Corn Subject to Oxidized and Acetylated-Oxidized Modification. International Food Research Journal, 17, 961-968.

[2] Aini, N., Hariyadi, P., Muchtadi, T.R. and Andarwulan, N. (2010) Hubungan Antara Waktu Fermentasi grits Jagung Dengan Sifat Gelatinisasi Tepung Jagung Putih Yang Dipengaruhi Ukuran Partikel. Jurnal Teknologi Dan Industri Pangan, 21, 18-24.

[3] Nago, M.C., Hounhouigan, J.D., Akissoe, N., Zanou, E. and Mestres, C. (1998) Characterization of the Beninese Traditional Ogi, a Fermented Maize Slurry: Phisicochemical and Microbiological Aspects. International Journal of Food Science Technology, 33, 307-315. http://dx.doi.org/10.1046/j.1365-2621.1998.00169.x

[4] Omar, N.B. and Ampe, F. (2000) Microbial Community Dynamics during Production of the Mexican Fermented Maize Dough Pozol. Applied \& Environmental Microbiology, 66, 3664-3673. http://dx.doi.org/10.1128/AEM.66.9.3664-3673.2000

[5] Rahmawati, Dewanti-Hariyadi, R., Hariyadi, P., Fardiaz, D. and Richana, N. (2013) Isolation and Identification of Microorganisms during Spontaneous Fermentation of Maize. Jurnal Teknologi Dan Industri Pangan, 24, 34-44.

[6] Suarni, U. (2005) Karakteristik Sifat Fisikokimia Dan Amilograf Tepung Jagung Sebagai Bahan Pangan. Prosiding Seminar Dan Lokakarya Nasional Makasar 2005. Pusat Penelitian Dan Pengembangan Tanaman Pangan. Badan Penelitian Dan Pengembangan Pertanian. Departemen Pertanian, South Jakarta City.

[7] Ghosh, B. and Ray, R.R. (2011) Current Commercial Perspective of Rhizopus oryzae: A Review. Journal of Applied Sciences, 11, 2470-2486.

[8] Tang, B., Pan, H., Tang, W., Zhang, Q., Ding, L. and Zhang, F. (2011) Fermentation and Purification of Cellulase from a Novel Strain Rhizopus stolonifer var. Reflexus TP-02. Biomass and Bioenergy, 36, 366-372. http://dx.doi.org/10.1016/j.biombioe.2011.11.003

[9] Heerd, D., Yegina, S., Tari, C. and Fernandez-Lahore M. (2012) Pectinase Enzyme-Complex Production by Aspergillus spp. in Solid-State Fermentation: A Comparative Study. Food and Bioproducts Processing, 90, 102-110. http://dx.doi.org/10.1016/j.fbp.2011.08.003

[10] Panagiotou, G., Kekos, D., Macris, B.J. and Christakopoulos, P. (2003) Production of Cellulolytic and Xylanolytic Enzymes by Fusarium oxysporum Grown on Corn Stover in Solid State Fermentation. Industrial Crops and Products, 18, 37-45. http://dx.doi.org/10.1016/S0926-6690(03)00018-9

[11] Li, X.Y., Liu, Z.Q. and Chi, Z.M. (2008) Production of Phytase by a Marine Yeast Kodamaea ohmeri BG3 in an Oats Medium: Optimization by Response Surface Methodology. Bioresource Technology, 99, 6386-6390. http://dx.doi.org/10.1016/j.biortech.2007.11.065

[12] Bussamara, R., Fuentefria, A.M., de Oliveira, E.S., Broetto, L., Simcikova, M., Valente, P., Schrank, A. and Vainstein, M.H. (2010) Isolation of a Lipase-Secreting Yeast for Enzyme Production in a Pilot-Plant Scale Batch Fermentation. Bioresource Technology, 101, 268-275. http://dx.doi.org/10.1016/j.biortech.2008.10.063

[13] Mohamed, L., Zakaria, M., Ali, A., Senhaji, W., Mohamed, O., Mohamed, E., Hassan, B. and Mohamed, J. (2007) Op- 
timization of Growth and Extracellular Glucoamylase Production by Candida famata Isolate. African Journal of Biotechnology, 6, 2590-2595.

[14] Wojtatowicz, M., Chrzanowska, J., Juszczyk, P., Skiba, A. and Gdula, A. (2001) Identification and Biochemical Characteristics of Yeast Microflora of Rokpol Cheese. International Journal of Food Microbiology, 69, 135-140. http://dx.doi.org/10.1016/S0168-1605(01)00582-7

[15] Omemu, A.M., Oyewole, O.B. and Bankole, M.O. (2007) Significance of Yeasts in the Fermentation of Maize for ogi Production. Food Microbiology, 24, 571-576. http://dx.doi.org/10.1016/j.fm.2007.01.006

[16] Zhu, L.J., Liu, Q.Q., Sang, Y., Gu, M.G. and Shi, Y.C. (2010) Underlying Reasons for Waxy Rice Flours Having Different Pasting Properties. Food Chemistry, 120, 94-100. http://dx.doi.org/10.1016/j.foodchem.2009.09.076

[17] Claver, I.P., Zang, H., Li, Q., Zhu, K. and Zhou, H. (2010) Impact of the Soak and the Malt on the Physicochemical Properties of the Sorghum Starches. International Journal of Molecular Sciences, 11, 3002-3015. http://dx.doi.org/10.3390/ijms11083002

[18] Sandhu, K.S., Singh, N. and Malhi, N.S. (2007) Some Properties of Corn Grains and Their Flours I: Physicochemical, Functional and Chapati-Making Properties of Flours. Food Chemistry, 101, 938-946. http://dx.doi.org/10.1016/j.foodchem.2006.02.040

[19] Xie, S.X., Liu, Q. and Cui, S.W. (2005) Food Carbohydrates: Chemistry, Physical Properties, and Applications. Taylor \& Francis Group, London.

[20] Oke, M.O. and Bolarinwa, I.F. (2012) Effect of Fermentation on Physicochemical Properties and Oxalate Content of Cocoyam (Colocasia esculenta) Flour. International Scholarly Research Network. ISRN Agronomy, 2012, Article ID: 978709. http://dx.doi.org/10.5402/2012/978709

[21] Zaidul, I.S.M., Norulaini, N.A.N., Omar, A.K.M., Yamauchi, H. and Noda, T. (2007) RVA Analysis of Mixtures of Wheat Flour and Potato, Sweet Potato, Yam, and Cassava Starches. Carbohydrate Polymers, 69, 784-791. http://dx.doi.org/10.1016/j.carbpol.2007.02.021

[22] Blazek, J. and Copeland, L. (2008) Pasting and Swelling Properties of Wheat Flour and Starch in Relation to Amylose Content. Carbohydrate Polymers, 71, 380-387. http://dx.doi.org/10.1016/j.carbpol.2007.06.010

[23] Wong, D.W.S. (1989) Mechanism and Theory in Food Chemistry. AVI Book, New York.

\section{List of Abbreviations}

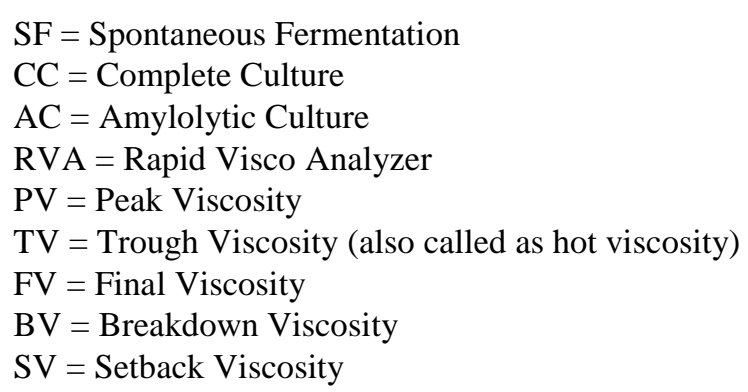


Scientific Research Publishing (SCIRP) is one of the largest Open Access journal publishers. It is currently publishing more than 200 open access, online, peer-reviewed journals covering a wide range of academic disciplines. SCIRP serves the worldwide academic communities and contributes to the progress and application of science with its publication.

Other selected journals from SCIRP are listed as below. Submit your manuscript to us via either submit@scirp.org or Online Submission Portal.
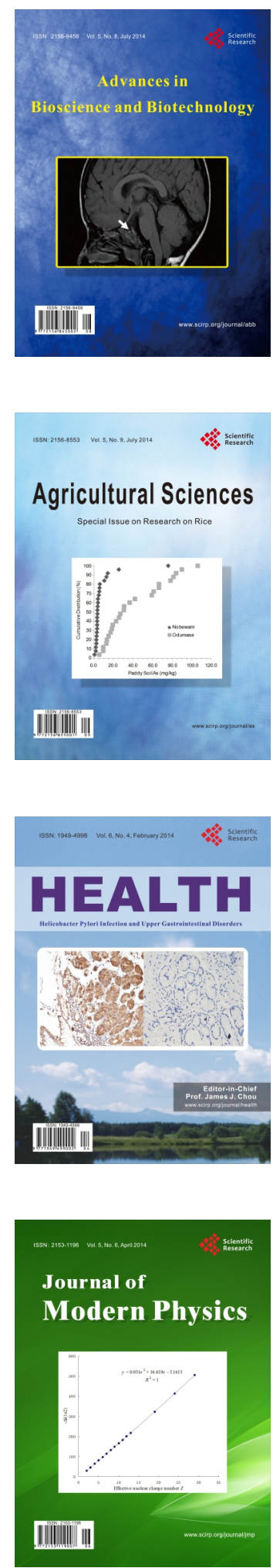
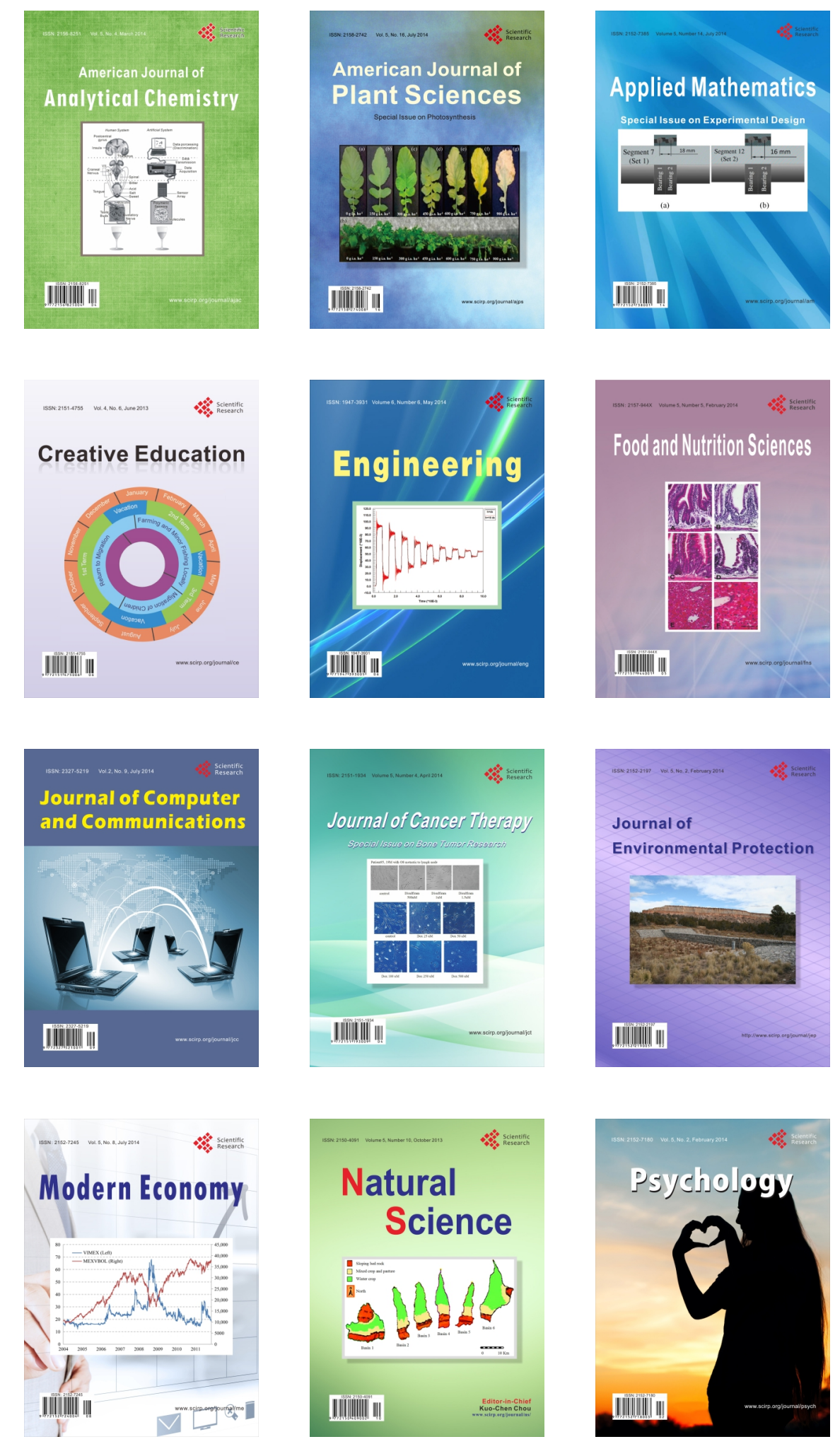